\title{
Pollution in the harbour of Ostend (Belgium). Biological and hydrographical consequences
}

\author{
Guido Persoone and Niels de Pauw \\ Laboratorium voor Oecologie, Biogeografie en Algemene Biologie, Rijksuniversiteit, \\ Gent, België, and Laboratorium voor Oecologie, Rijksuniversitair Centrum, \\ Antwerpen, Belgie
}

\begin{abstract}
EXTRAIT: La pollution dans le port d'Ostende (Belgique). Conséquences biologiques et hydrographiques. Le port d'Ostende reçoit chaque jour une quantité importante d'eaux polluées d'origine terrestre. A marée basse les égoûts de la ville et des faubourgs se déversent dans le port par trois émissaires. De plus, les canaux Noord-Eede et Ostende-Bruges amènent les eaux noires de plusieurs villes situées à l'Est d'Ostende. Rien que pour les égoûts de la ville même, ceci signifie un apport journalier de 3 à 6 litres d'eaux usées par $\mathrm{m}^{3}$ d'eau portuaire. Des analyses sur la physico-chimie, la bactériologie, le plancton et le biotecton, effectuées à 3 points différents du port (A: à l'entrée du chenal; B: dans l'avant-port; C: à l'entrée de l'arrière-port) nous ont permis de tirer les conclusions suivantes: (a) Le déficit en oxygène dissous est très grand surtout dans l'avant ct l'arrière-port. (b) Il y a un nombre énorme de bactéries portuaires («estuarine» bacteria) à la suite du grand apport de matières organiques. (c) Le nombre de bactéries coliformes est très grand et décroît de l'avant-port vers le chenal. (d) Les courants marins refoulent une partie des eaux polluées vers les plages voísines. (e) La très grande turbidité de l'eau dans le port gêne considérablement la production phyto-planctonique. (f) Le benthos est complètement anoxique et riche en matières organiques et en sulfures. Il ne contient plus de protistes ni d'invertébrés. (g) Par suite de l'apport régulier de déchets riches en matières organiques le biotecton se développe considérablement. Il est constitué pour la majeure partie d'organismes bactériophages et détritivores.
\end{abstract}

\section{INTRODUCTION}

The city of Ostend is economically characterized by fishery; during the summer months it is a typical seaside resort with its normal population of 60,000 inhabitants increasing to about 200,000 in July and August.

The harbour of Ostend consists of three parts: the channel, the outer-harbour and the inner-harbour (Fig. 1). The draught in the outer-harbour (which is connected with different basins) is $4 \mathrm{~m}$, in the channel $4.7 \mathrm{~m}$ at mean low water spring. The tidal range is mostly around $5 \mathrm{~m}$. The inflow of sediments from the North Sea is very important and the thickness of the mud layer increases by almost $1 \mathrm{~cm}$ daily, so that at some points it reaches $1 \frac{1}{2} \mathrm{~m}$. To preserve the necessary draught, $10^{6} \mathrm{~m}^{3}$ are dredged out yearly.

All sewage from Ostend and its suburban districts is drained into the harbour 
without any previous treatment. Sewers enter the harbour at three points: "Visserskreek", "De Mey sluis", and "Spuisluisbrug".

At low tide all the wastes accumulated in the sewers are released into the harbour water. Roughly estimated this means an input approximately $8,000 \mathrm{~m}^{3}$ per day rising to more than $15,000 \mathrm{~m}^{3}$ during the summer months. In relation to the water volume of the harbour (an estimated $1,3.10^{6} \mathrm{~m}^{3}$ at low tide), this means an inflow of 3 to 6 litres sewage per $\mathrm{m}^{3}$ harbour water, twice a day. Moreover, there is the waste of

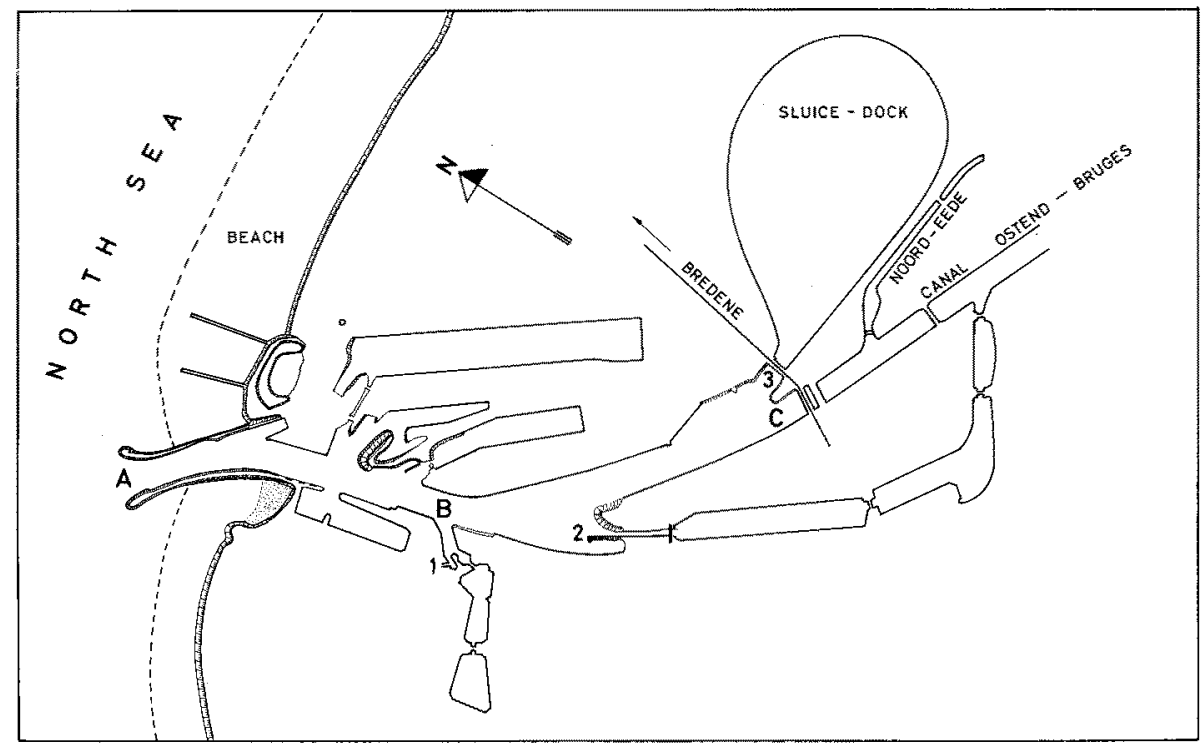

Fig. 1: Harbour of Ostend with (a) sampling points: (A) at the Pier, (B) in the outer harbour, (C) at the beginning of the inner harbour; (b) mouths of sewers: (1) "Visserskreek", (2) "De Mey sluis", (3) "Spuisluisbrug"

the canal Noord-Eede which ends in the inner-habour and is strongly polluted by sewage from different cities located eastward of Ostend. This water is drained into the harbour once or twice a day during 2 to 8 hours. Unfortunately, the volume of this input is not known. The last source of pollution comes from the canal OstendBruges, which carries waste from as far as Bruges.

Due to the low water-mark of this canal, the sluices of the inner-harbour are usually closed during summer; but there is always a certain volume of new water which enters the harbour during, the passing of ships. At all other times of the year, there is a large inflow ( 30 to $60 \mathrm{~m}^{3} / \mathrm{sec}$ ). As will be shown, this inflow has an important influence on the salinity of the harbour water.

In addition to the total input of domestic sewage, industrial waste products of 2 factories, situated outside Ostend, partly enter via the canal Ostend-Bruges, and partly through the sewers entering the harbour at the "De Mey sluis".

Early biological observations and samplings in the harbour of Ostend were carried out by Gilson (unpublished), Scrulz (1925), Leloup \& van MeEl (un- 
published). The first complete study on the hydrography and biology of this estuary was published by Lefevere, Leloup \& van Meel (1956).

From 1963 to the present time, we have tried to add to the knowledge of this estuary by investigations on physico-chemistry, bacteriology, plankton and "Aufwuchs". In order to compare our results with the work of LEFEVERE, LELOUP \& VAN

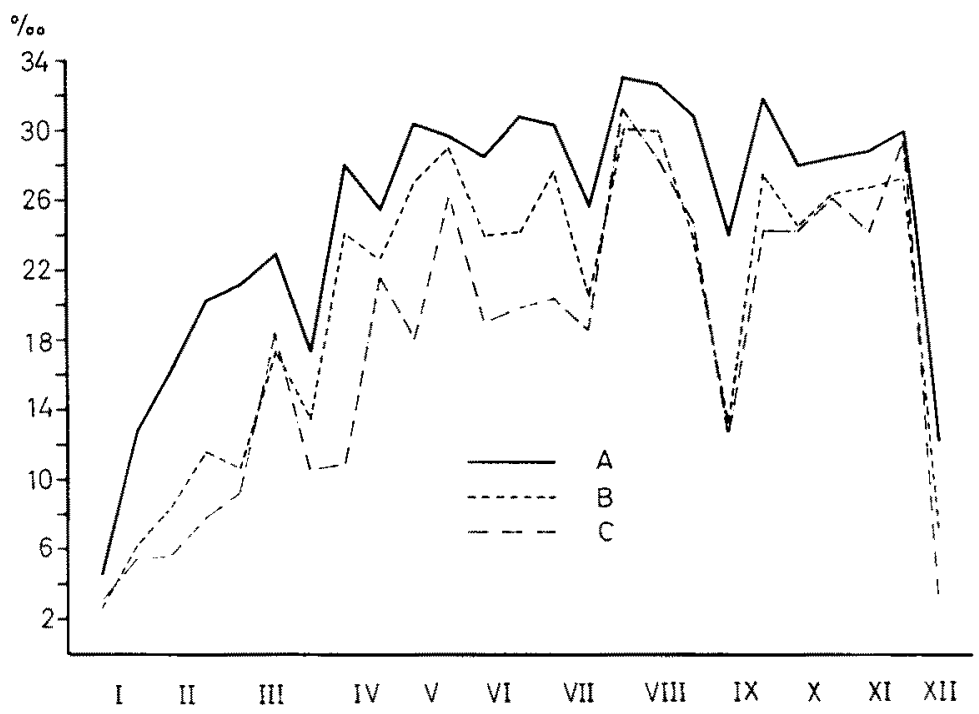

Fig. 2: Salinity in the Ostend harbour during 1965 at sampling points $A, B, C$

Mres (1956), we chose the same sampling places: points A, B and C. Point A is located at the end of the pier, which lies about $250 \mathrm{~m}$ off the coast-line at low tide, and $400 \mathrm{~m}$ at high tide. Point $\mathrm{B}$ lies approximately at the mouth of the "Visserskreek", point $C$ at the top of the inner-harbour, near the sluices of the canal Ostend-Bruges and the Sluice-dock.

\section{RESULTS}

\section{Physico-chemistry}

Water temperature follows the normal seasonal changes from a minimum of $\pm 1^{\circ} \mathrm{C}$ to a maximum of $\pm 25^{\circ} \mathrm{C}$; it is usually a few degrees higher at point $\mathrm{C}$ than at point $\mathrm{A}$. harbour.

$\mathrm{pH}$ is alkaline, varying between 7 and 8 , and about uniform throughout the

Salinity is very low in January and increases considerably until May, remains at this level until October and then decreases again to the winter level (Fig. 2). The influence of the inflow of freshwater coming from the canal Ostend-Bruges is 

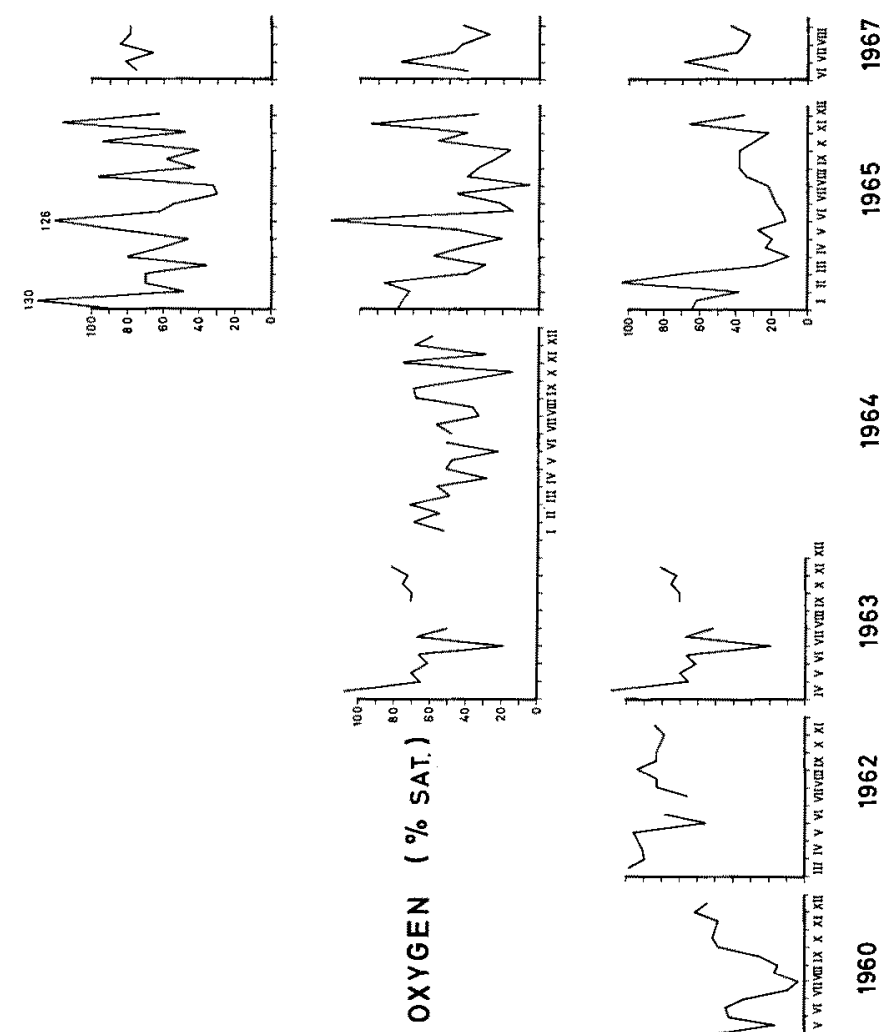

$\dot{0}$

$\stackrel{\circ}{\circ}$
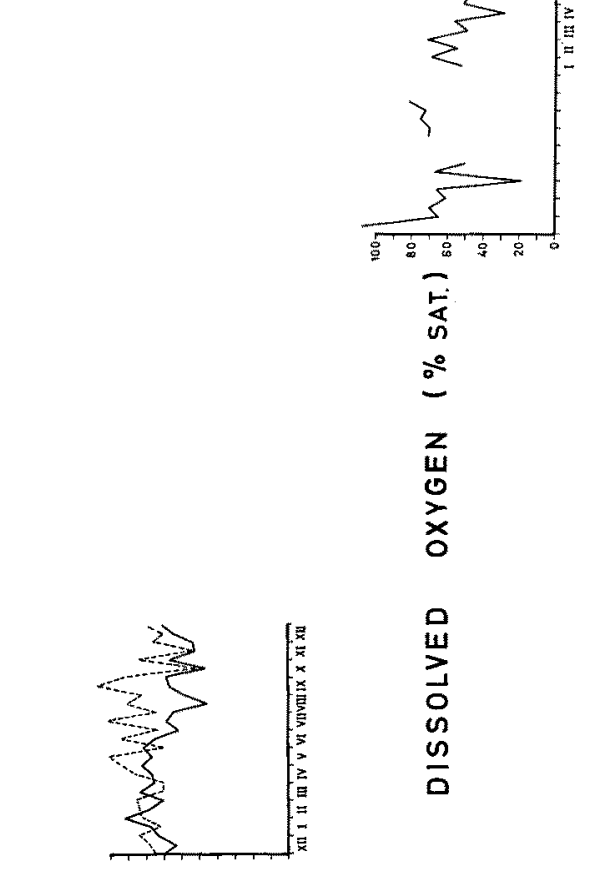

0
$u$
3
0
n
on
0

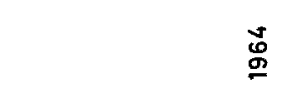

\&
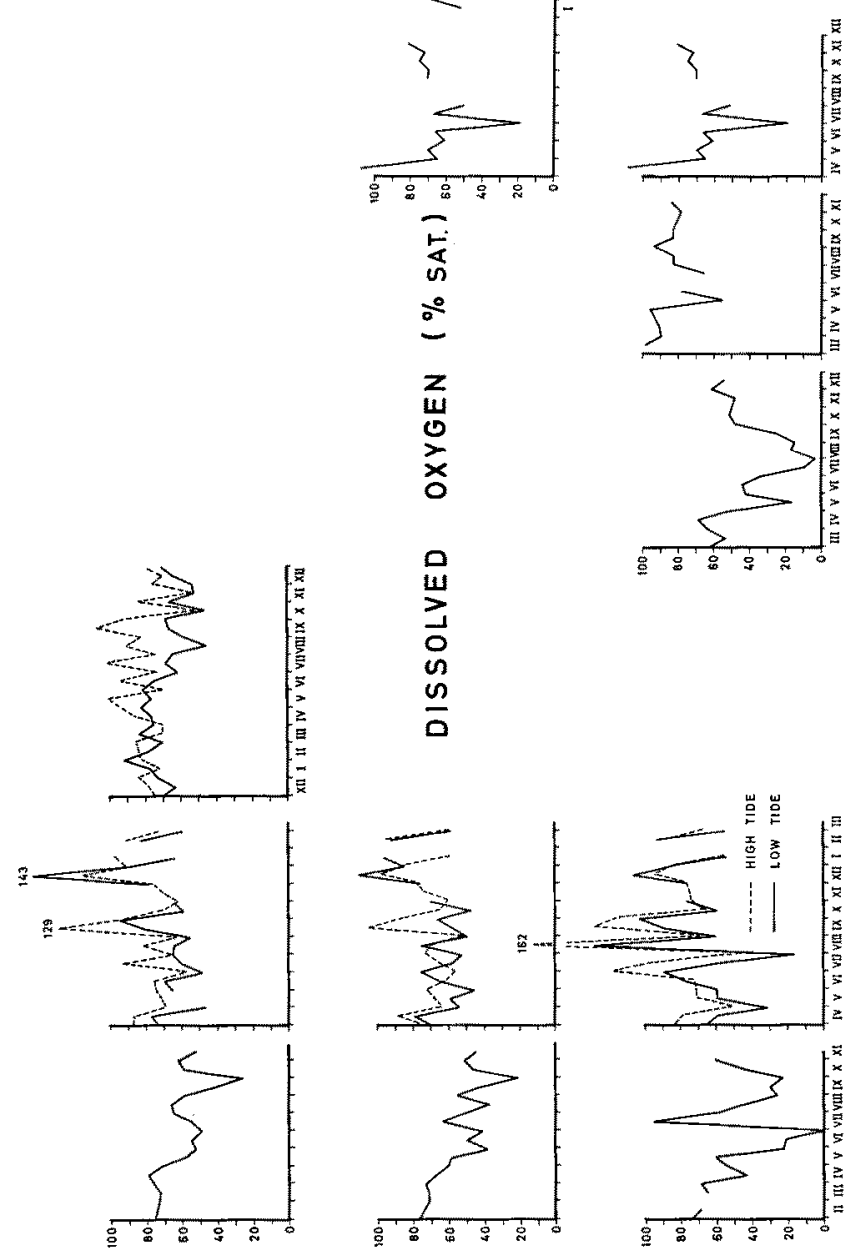

8

昜
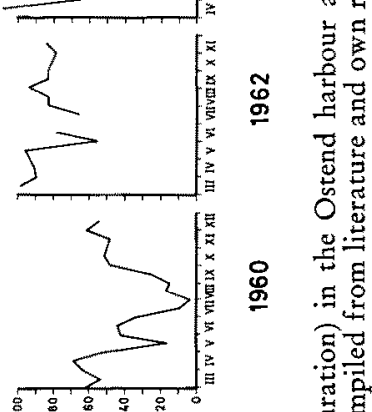

ㅂ.

용

.

苇

要

응

落泀

爻

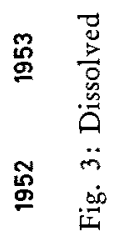

$\varangle$

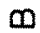

0 
apparent. According to the Venice-system (1958), the water is mixohaline, in the range from bêta-oligohaline (during winter) to polyhaline (during summer).

Dis s o lved oxygen data from the literature, as well as our own measurements, are illustrated graphically in Figure 3. The results obtained 1949, 1952 and early 1953 are from Lefevere, Leloup \& VAN MEel (1956), those of 1954 from Van MeEL (1964), those of 1960, 1962, 1963 (at point C) from the "Commission T.W.O.Z.Groupe de Travail Ostreiculture" and those of 1963 and 1964 (at point B) from Leloup \& POLK (1967). The most relevant observation is the marked deficit of dissolved oxygen throughout the harbour. In the inner-harbour, although the values may fluctuate strongly, it is clear that during most recent years the oxygen deficit is very important (only 20 to $50 \%$ saturation). The outer-harbour is influenced by the daily input of sewage, which contains mostly no oxygen, and by the tide which brings fresh sea-water, rich in oxygen. This is appearent from observations made for several years at high and low tides (Fig. 3). As a whole, the outer-harbour has also an important oxygen deficit; especially during the most recent years, $\mathrm{O}_{2}$ concentration is mostly under $50 \%$ saturation. Even in the channel, at the end of the pier, there is a shortage of dissolved oxygen. At the "Goote Bank" (20 km offshore), water samples showed $100 \%$ and more saturation.

Oxygen demand was determined this year several times. After two days, practically all the oxygen had disappeared in samples obtained at the three points. The oxygen demand of the harbour water is higher than $5 \mathrm{mg} /$ litre within 48 hours, while water from the "Goote Bank" showed an oxygen demand of 0.4 to $0.8 \mathrm{mg} / \mathrm{litre}$, during the same period of time.

Transparency, as determined by means of a Sechi-disc, is very low throughout the harbour, i. e., between 30 and $40 \mathrm{~cm}$. At the "Goote Bank", it ranges from 2 to $6 \mathrm{~m}$. The main reason for the low transparency in the harbour is the high concentration of suspended material, mainly due to whirling up of benthos material by tidal currents and the passing of ships. After filtration of different samples of seawater through a membrane filter, we obtained a dry weight of 75 to $150 \mathrm{mg} / \mathrm{l}$, the plankton content of which amounted to less than $1 \%$. We found 20 to $70 \mathrm{mg} / \mathrm{l}$ in the "Westerschelde"; at the "Ankerstation Scheelenkuhlen" in the lower Elbe, Koske, Krumm, Rheinheimer \& Szekielda (1966) recorded 50 to $200 \mathrm{~m} / \mathrm{l}$.

\section{Bacteriology}

The number of bacteria in the harbour water was determined for the first time in 1964 (PERSOONE 1966). In order to cultivate the highest possible number of "estuarine bacteria"1, different solid culture media were compared, as well as two ways of pouring out. The following medium, a modification of $2216 \mathrm{E}$ of ZoBeLL appeared to give the best results:

1 We used this term (SIEBuRTh 1965) to characterize all bacteria able to grow on media prepared with sea-water. It includes the "halotolerante" which can grow in sea-water and in freshwater, and the "halophile" which only grow in media containing a certain concentration of salt (RHEINHEIMER 1966). 


$\begin{array}{lrlr}\text { Peptone } & 5 \mathrm{~g} & \mathrm{FePO}_{4} & 0.1 \mathrm{~g} \\ \text { Glucose } & 1 \mathrm{~g} & \text { Aqua destillata } & 250 \mathrm{ml} \\ \text { Yeast Extract } & 0.1 \mathrm{~g} & \text { Aged sea-water } & 750 \mathrm{ml} \\ \text { Agar } & 15 \mathrm{~g} & & \end{array}$

The $\mathrm{pH}$ was adjusted with $1 \mathrm{~N} \mathrm{NaOH}$ so as to obtain a final $\mathrm{pH}$ of $7.6 \pm 0.1$.

The inoculation according to classical pour plates after $\mathrm{KoCH}$ gave better results than surface plating. The number of colonies on the agars was counted after 9 to 12 days incubation at $20^{\circ} \mathrm{C}$.

On the classical Nutrient Agar, prepared with freshwater (Standard Methods for the Examination of Water and Wastewater) and incubated at $37^{\circ} \mathrm{C}$, we found only $40 \%$ of the number of colonies obtained with the former sea-water agar.

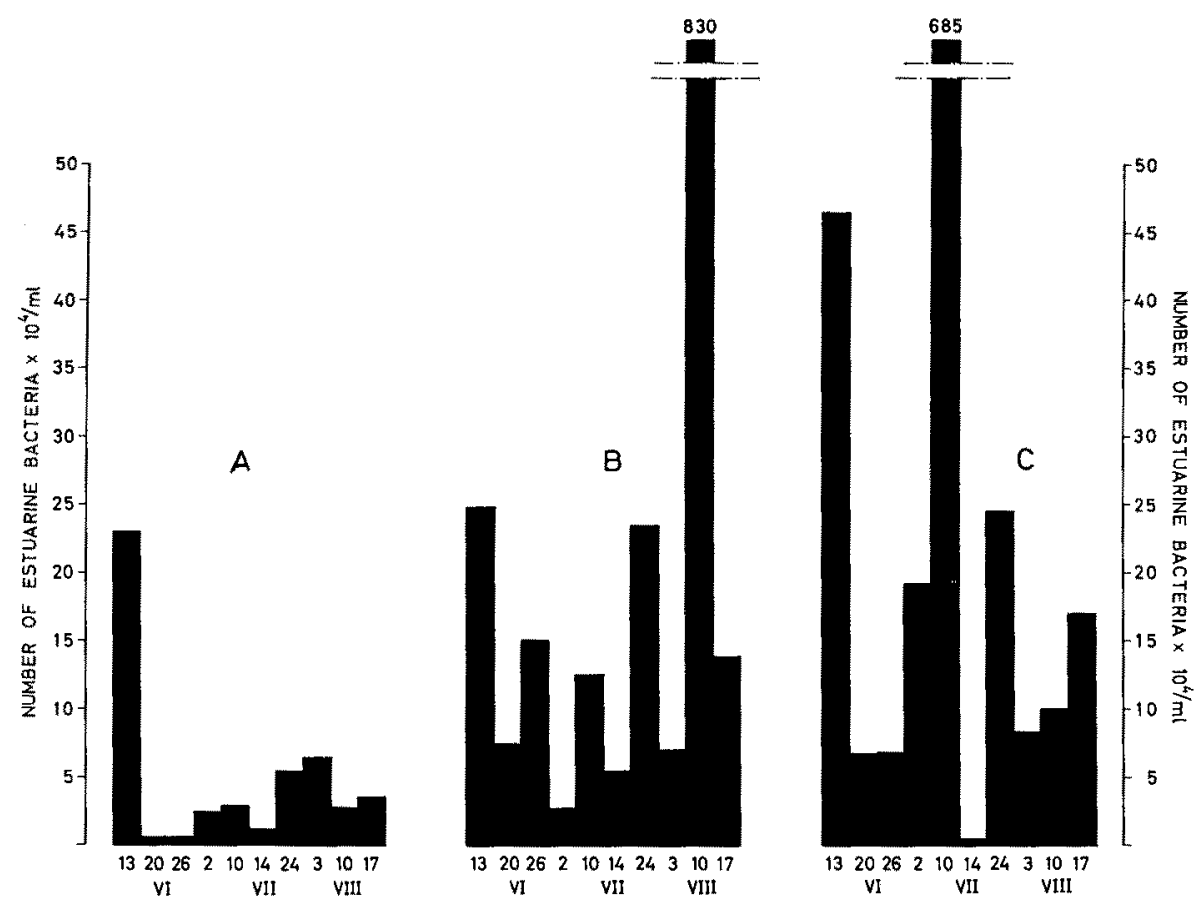

Fig. 4: Number of estuarine bacteria $\left(\mathrm{x} 10^{4} / \mathrm{ml}\right.$ ) at points A, B, C; weekly observations in June, July and August, 1967

On February 5, 1964, we found 20,000 bacteria/ml at point B, and on February 25 and March 5, 1964, about 300,000/ml. This year, in June, July and August, we have determined the number of estuarine bacteria in the harbour weekly at the three sampling places A, B and C (Fig. 4). At the end of the pier, where the harbour water is mixed continuously with fresh sea-water, we usually found numbers ranging from 10,000 to $60,000 / \mathrm{ml}$. In the outer-harbour this number is higher: 30,000 to $250,000 / \mathrm{ml}$, with a maximum of $830,000 / \mathrm{ml}$. As appears from the graph there are rather important 
fluctuations in these numbers. The influence of the tide is apparent, the highest numbers being found at low tide or when the tide is ebbing. At point $C$, at the top of the inner-harbour, we frequently found very high numbers. However, here the spreading is very high (minimum $3,500 / \mathrm{ml}$, maximum $685,000 / \mathrm{ml}$ ).

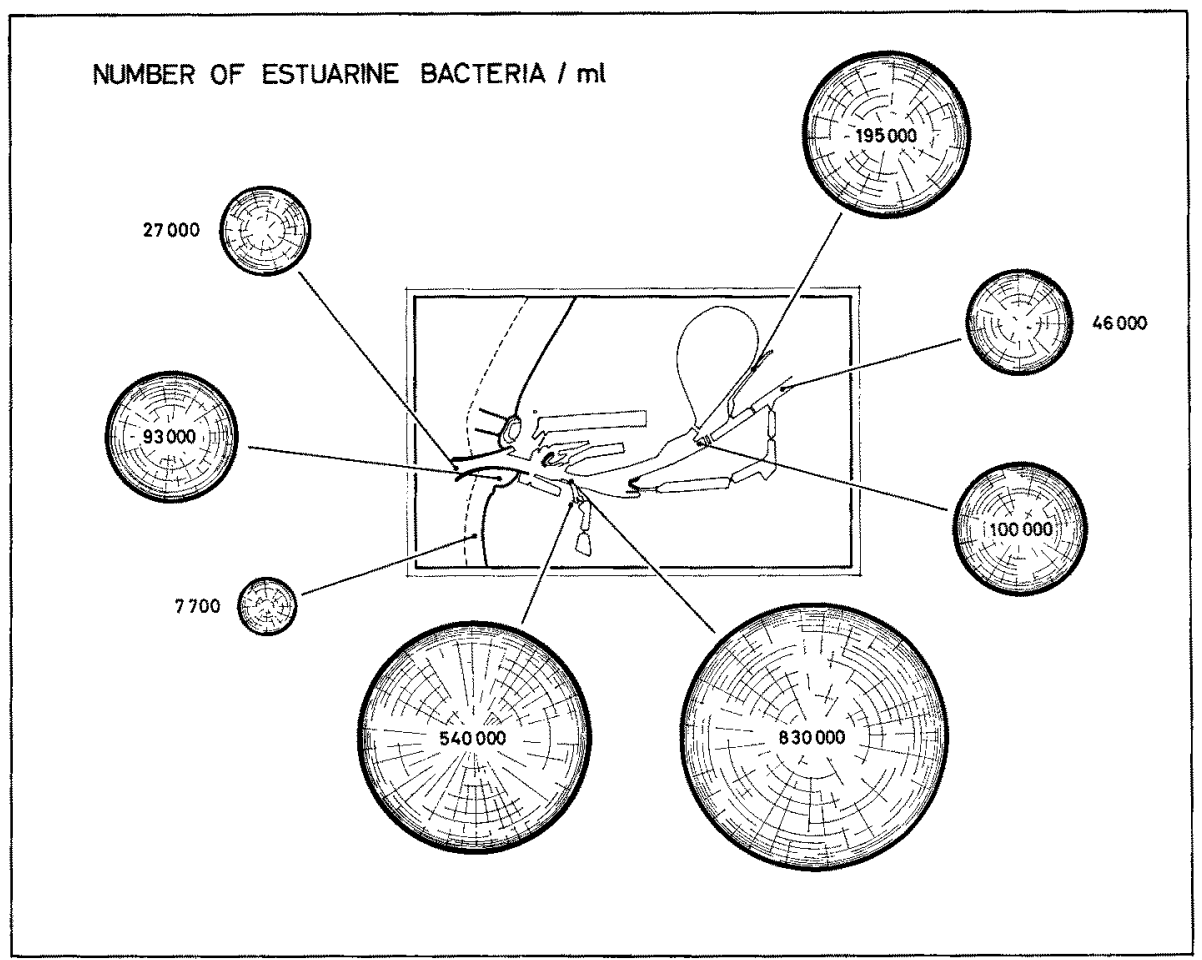

Fig. 5: Number of estuarine bacteria/ml (spheres) at 8 sampling points throughout the Ostend harbour on August 10, 1967

On August 10, 1967, we made a comparative bacteriological analysis of different places all over the harbour. The samples were taken between 1 and 2 hours after low tide. In Figure 5 we have illustrated the number of estuarine bacteria of each sampling point, in three dimensions, with spheres. The highest numbers were noted at the "Visserskreek" (at the mouth of the sewers), as well as at point B where the "Visserskreek" enters the outer-harbour $(500,000$ to 830,000 bacteria/ml). Even the "NoordEede" (brackish water) and the canal Ostend-Bruges (oligohaline), which both contain strongly polluted water, show high numbers of estuarine bacteria (about 200,000 and $50,000 / \mathrm{ml}$, respectively). At the entrance of the harbour, the current is flowing towards the West when tide is ebbing, hence, the polluted harbour water comes in direct contact with the nearest part of the beach; at this place we found almost 100,000 bacteria $/ \mathrm{ml}$. One $\mathrm{km}$ further, the number of estuarine bacteria decreased to about $8,000 / \mathrm{ml}$. 
The number of bacteria per $\mathrm{ml}$ harbour water is exceptionally high as compared with the numbers of marine bacteria in the North Sea. Gunkel (1964) mentions figures from a few thousands to $10,000 / \mathrm{ml}$ at the "Helgoländer Kabeltonne". In the vicinity of river-mouths higher numbers were found; thus Gunkel (1963) reports 15,000 (surface) to 27,000 bacteria/ml $(10 \mathrm{~m} \mathrm{depth})$ at the mouth of the Weser close to Bremerhaven. Rheinheimer (1966) found up to 15,000 estuarine bacteria/ml in the "Nord-Ostsee-Kanal" and more than $20,000 / \mathrm{ml}$ in the "Kieler Bucht" in the vicinity of the mouth of a sewer at Bülk. At the mouth of the "Westerschelde", we found from 5,000 to $15,000 / \mathrm{ml}$ in July 1967.

All marine bacteriologists agree that the number of bacteria in a given biotop is principally a function of the concentration of organic matter. ZoBell (1957) writes: "The numbers and kinds of bacteria in the sea are influenced by the organic content of water, the presence of suspended solids to which bacteria can attach, the occurrence of other organisms and a multiplicity of other interrelated factors. The low concentration of organic matter appears to be the principal factor that limits the bacterial population." As we already have shown, the amount of suspended material in the harbour water of Ostend is very important. Ignition loss amounted to 40 to $80 \%$ of the dry weight.

By means of the permanganate-method in alkaline medium (after WINKLER), we have further determined the concentration of the dissolved organic matter after filtrating the water through a membrane filter. The permanganate used was usually higher than $60 \mathrm{mg} / 1$. The high concentration of organic matter, as a result of the daily input of high quantities of domestic sewage, and the high turbidity of the water, explain these high numbers of bacteria.

According to ZoBell \& Feltham (1942): "Aquatic bacteria consume an average of $14.9 \times 10^{-12} \mathrm{ml}$ of oxygen per cell per hour in sea-water at $22^{\circ} \mathrm{C}$ and considerably more than this at higher temperatures..." HARvEY (1955) writes: "one gram of actively growing marine bacteria consumes about $30 \mathrm{cc}$ of oxygen per hour." The enormous amount of bacteria seems then to be the essential cause of the oxygen depletion in the harbour.

Table 1

Numbers of estuarine bacteria and saturation values of dissolved oxygen at points A, B and C (average values)

\begin{tabular}{|c|c|c|c|}
\hline \multirow{2}{*}{ Criteria } & \multicolumn{3}{|c|}{ Sampling points } \\
\hline & A & $\mathrm{B}$ & $\mathrm{C}$ \\
\hline Number of estuarine bacteria/ml & 28,000 & 131,000 & 135,000 \\
\hline Dissolved oxygen ( $\%$ saturation) & 75 & 45 & 42 \\
\hline
\end{tabular}

Table 1 gives median values of the number of estuarine bacteria and the percentage saturation of dissolved oxygen for samples obtained in June, July, and August, 1967. The lowest number of germs (point A) corresponds to the highest saturation value of dissolved oxygen; at points $B$ and $C$, higher numbers of bacteria, and lower saturation values were found. 
In order to assess the importance of pollution by faecal matter, we have also determined the number of coliform bacteria on Mc Conkey agar (Fig. 6). At point B, the highest number of coliforms was found due to the vicinity of the mouth of the sewer in the "Visserskreek". The time of sampling appeared to be very important since sewage is discharged only around low tide. When we took samples at, or immediately after, low tide, we found 2,500 to 3,500 coliforms $/ \mathrm{ml}$, while at high tide
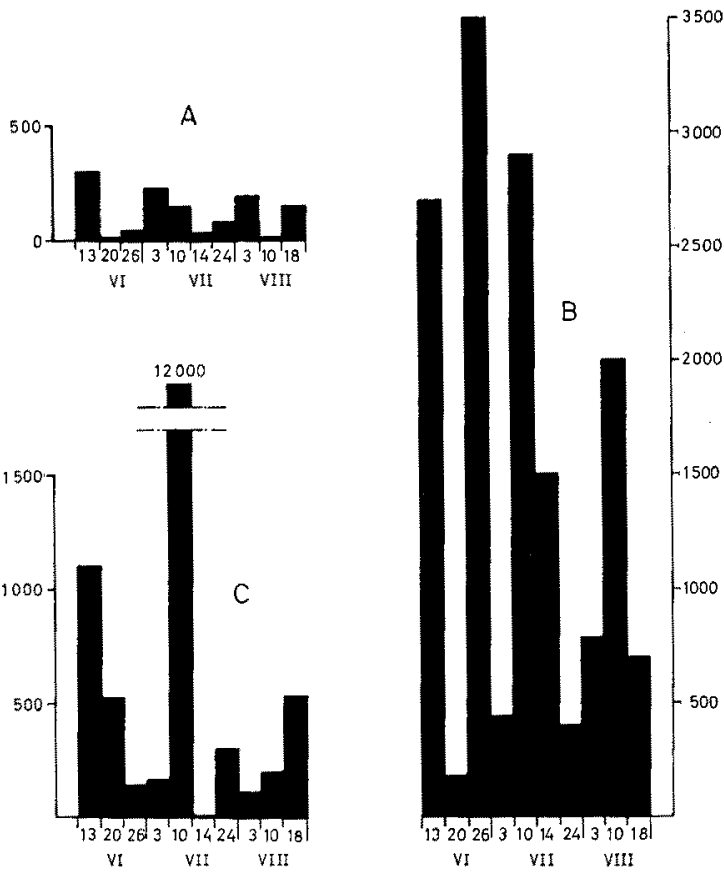

Fig. 6: Number of coliform bacteria/ml at points $\mathrm{A}, \mathrm{B}, \mathrm{C}$; weekly observations in June, July and August, 1967

there were only a few hundreds/ml. At point $\mathrm{C}$, the numbers fluctuate very irregularly (from $10 / \mathrm{ml}$ to $12,000 / \mathrm{ml}$ ); this fact can be explained by the diverse influences to which this point is subjected. At the end of the pier we found 6 to 300 coliforms $/ \mathrm{ml}$.

Together with the investigation on estuarine bacteria, we also determined the number of coliforms throughout the harbour on August 10, 1967 (Fig. 7). We found a very high number of coliform bacteria at the mouth of the sewer (about $40,000 / \mathrm{ml}$ ). The occurrence of high numbers of coliforms in the Noord-Eede is striking $(24,000 / \mathrm{ml})$. No dissolved oxygen has been found either in the "Visserskreek" nor in the NoordEede; this finding demonstrates sufficiently the high degree of pollution at these places. In the canal Ostend-Bruges, and at the other places of the harbour, we found 200 to 2,000 coliform bacteria $/ \mathrm{ml}$. At the top of the pier and at the beach 6,26 and 8 coliforms $/ \mathrm{ml}$, respectively, were found.

The fast disappearance of Enterobacteriaceae in seawater has already been the 
subject of many investigations; the pertinent bibliography has been summarized by Paoletti (1964).

From the results presented above it is evident that the harbour of Ostend is a very dirty estuary; the degree of its pollution increases continuously and extends more and

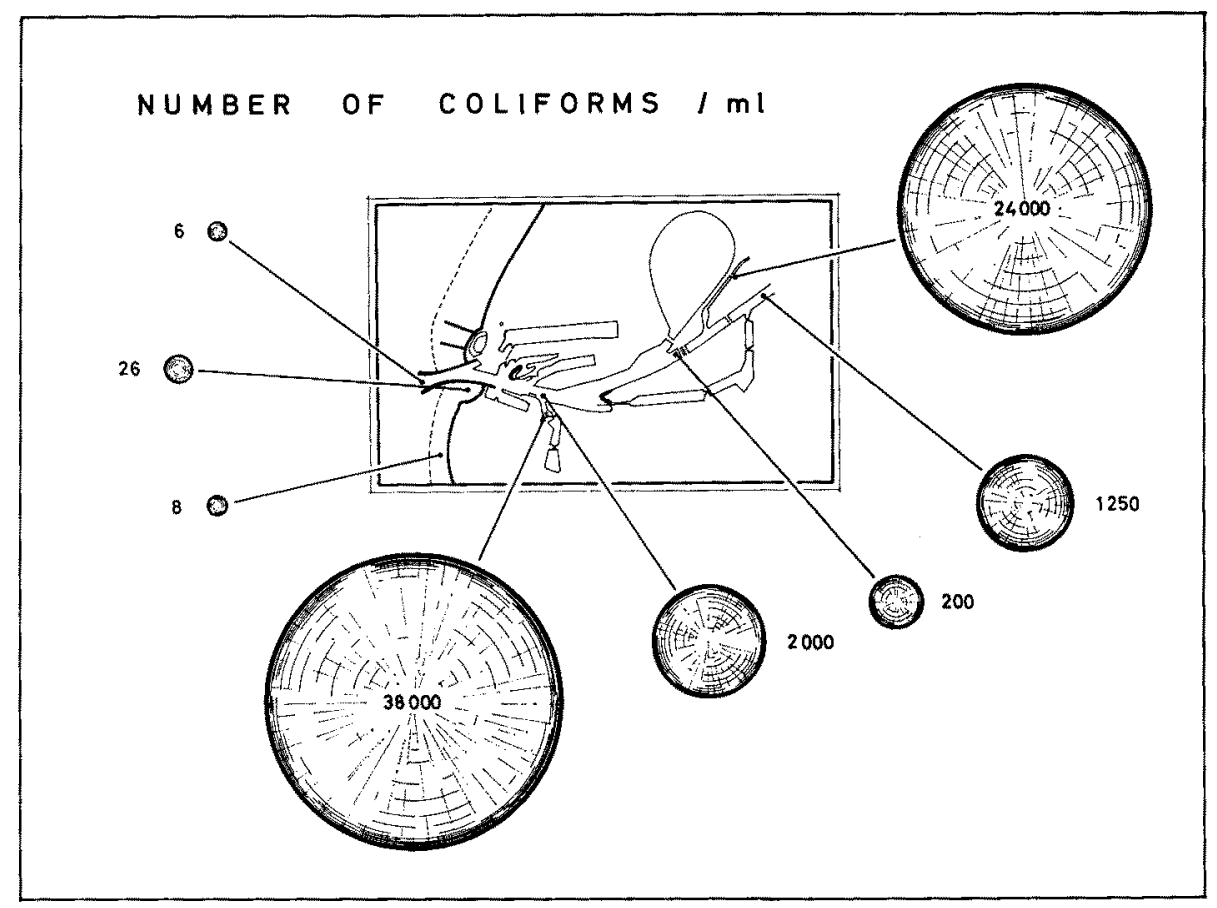

Fig. 7: Number of coliform bacteria/ml (spheres) at 8 sampling points throughout the Ostend harbour on August 10, 1967

more to the nearest part of the beach. This is not the first statement of this kind; in 1956, Lafontaine, de Maeyer-Cleempoel \& Bouquiaux have repeatedly found 10 to 20 Escherichia coli $/ \mathrm{ml}$ at eleven sampling points along the Belgian coast.

It is not our intention to interpret these numbers of coliform bacteria in regard to public health. During several international congresses on water pollution these questions have been treated "in extenso" by numerous specialists (for example in Nice 1949, in Biarritz 1950, in Bordeaux 1954, again in Nice 1958, in Cincinnati 1959, in Berkeley 1959, in London 1962, in Monaco 1964, and in Tokyo 1964).

\section{Plankton}

In 1965, samples were taken twice a month at points $\mathrm{A}, \mathrm{B}$ and $\mathrm{C}$, in order to study the qualitative and quantitative composition of the phyto- and zooplankton in the harbour (DE PAUw 1966). 


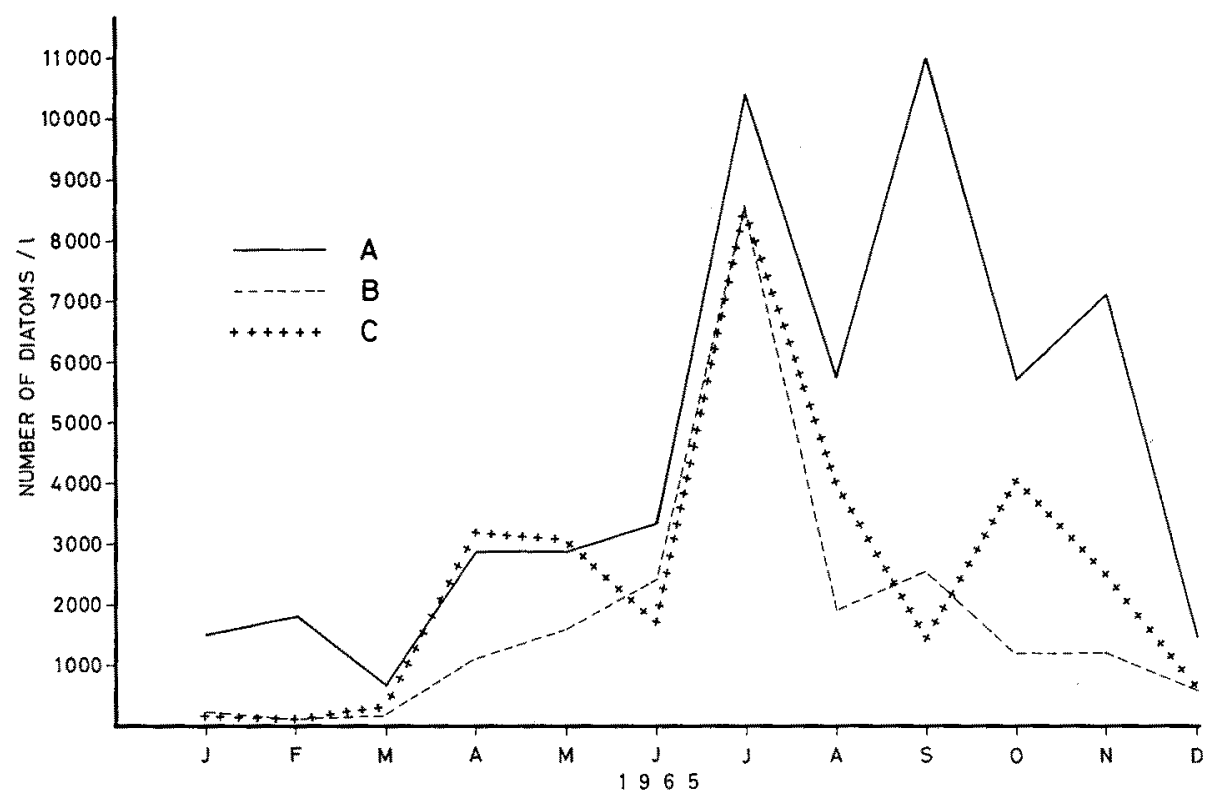

Fig. 8: Number of diatoms/l at points A, B, C during 1965

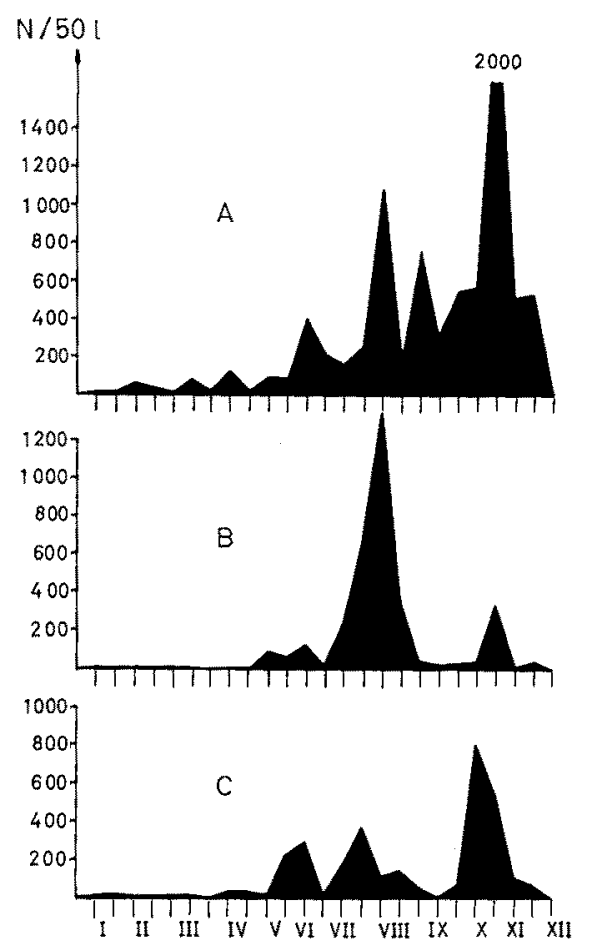

Fig. 9: Number of copepods/50 1 at points A, B, C during 1965 
In regard to the phytoplankton, diatoms are by far the dominanting group. The number of peridinians reached a maximum of 50 individuals $/ 1$, and the number of planctonic Chlorophyceae (mostly freshwater forms) was 150 to 200 cells/l. The number of diatoms (Fig. 8) was, with a few exceptions, always highest at the pier. The higher number in $C$, as compared to $B$, can be explained by the regular supply of freshwater species from the Noord-Eede or the canal Ostend-Bruges. The number of diatoms in the harbour seems to be within the same range as at the "Goote Bank" $(10,000$ to $12,000 / 1$ on June 28,1967$)$ or at the mouth of the "Westerschelde" $(5,000$ to $20,000 / 1$ on July 7,1967$)$. Nevertheless, during microscopical analysis we could observe each time that most cells showed shrinkage of chloroplasts or that they had lost their cytoplasm completely. We are convinced that the presence of a certain number of diatoms in the harbour is due to the daily tide-inflow of new individuals. However, the majority of these immigrants dies quickly, and the reproduction of the rest is probably inhibited by the low water transparency. The concentration of dissolved oxygen in the harbour water is thus maintained only via the mixing with fresh sea-water.

In regard to the zooplankton we have to distinguish: (a) typical zooplankton and (b) pelagic larval stages of hemi-sessile or sessile invertebrates (the latter group will be included in the discussion of the "Aufwuchs"). The typical zooplankton of the harbour consists almost exclusively of crustacean copepods of which 4 species are quantitatively important: the cyclopoid Cyclopina littoralis (BRADX), and the calanoids Acartia bifilosa Giesbrecht, Centropages hamatus Lilljeborg and Temora longicornis (MULLER). The number of copepods at point $A$ appeared to be within the same range as in the zooplankton of the North Sea (RAymont 1963). However, the number decreases from the outer to the inner-harbour (Fig. 9).

\section{Benthos}

The sediments in the harbour consist mainly of black mud which strongly smells of sulfides. With the exception of anaerobic bacteria, we never found any trace of animal life in this anoxic environment. In Table 2, we have compared the amount of organic matter (ignition loss) in sediments of the harbour, with pertinent values

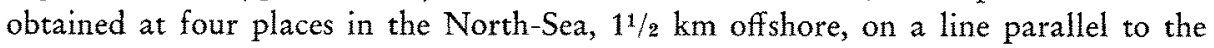
coast ${ }^{2}$. From this comparison we conclude that the concentration of organic matter is clearly higher in the harbour sediments (sand as well as mud) than in the North Sea.

According to Hata, Kadota, Mryoshi \& Kimata (1965), the number of sulforeducing bacteria and the concentration of sulfides in sediments is directly correlated with the amount of organic matter" "... a large amount of organic matter brought on to the bottom mud by sewage or industrial wastes stimulates the growth and physiological activity of sulfate-reducing bacteria, and subsequently causes the vigorous production of sulfides in the bottom sediments in coastal sea or estuary polluted

2 The possible presence of carbonates in these sediments was not taken into account.

${ }^{3}$ At least with the easily decomposable parts of it, expressed as C. O.D. values. 
Table 2

Nature of the sediments and percentage organic matter at: sampling points $A, B, C$ in the

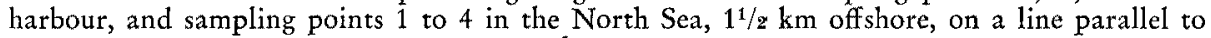
the coast

\begin{tabular}{|clllc|}
\hline Sampling place & Location & $\begin{array}{l}\text { Nature of } \\
\text { substrate }\end{array}$ & Colour & $\begin{array}{c}\% \text { Organic matter } \\
\text { (ignition loss) }\end{array}$ \\
\hline A & Harbour & Coarse sand +mud & Black & 3.4 \\
B & Harbour & Mud & Black & 15.2 \\
C & Harbour & Mud & Black & 12.8 \\
1 & North Sea & Mud & Light grey & 9.6 \\
2 & North Sea & Coarse sand & Light grey & 1.1 \\
3 & North Sea & Fine sand & Light grey & 2.3 \\
4 & North Sea & Fine sand +mud & Black & 11.0 \\
\hline
\end{tabular}

with organic drainages." The daily inflow of domestic sewage thus appears to have killed all organisms except Schizomycetes, by exhaustion of the oxygen supply and the formation of great quantities of sulfides (both due to bacterial activity).

\section{Aufwuchs}

During our investigations on the "Aufwuchs" on submerged substrates we have determined the settling periods of the principal fouling organisms as well as the qualitative and quantitative composition of the "Aufwuchs"-biocoenosis (Persoone 1967a). We noted that the "Aufwuchs" can reach enormous proportions. A frame with slides submerged in the outer-harbour during June 1964 was entirely covered by a thick mud layer (weighing more than $30 \mathrm{kgs}$ ) when we took it out two months later. This was the result of the explosive settling and development of a hemi-sessile polychaet Polydora ciliata (Johnston), which gathers mud particles to build its tubes (PeRSOONE 1965). Due to the important amount of material in suspension, more and more mud and detritus is accumulating on the slides (Fig. 10) which finally resulted in this enormous mud layer. The concentration of organic matter in the mud and detritus (which constitute an important part of each Aufwuchs) is very high (up to $23 \%$ ). The immediate result of this is the development of a great number of bacteria.

During a series of experiments with substrates submerged for 15 days, we counted $10^{8}$ to $10^{9}$ bacteria per $\mathrm{cm}^{3}$ of mud, i. e., 1,000 to 10,000 times more than in the harbour water. Undoubtedly these high numbers of mud bacteria play also an important role in the exhaustion of oxygen.

The enormous numbers of Leucothrix-trichomes found on all submerged slides during the year, are striking. The germination into gonidia, its settling, the aggregation in "rosettes" and the development into trichomes have been described by HAROLD \& Stanter (1955) see also (Fig. 11). According to Hutner (quoted by Harold \& STaNIER) these chemoheterotrophic Leucothiobacteriaceae are strict aerobes with an optimum temperature around $25^{\circ} \mathrm{C}$ and optimal growth rates at a salt concentration of $16 \mathrm{~g} / 1$. According to BERGER \& BRINGMANN (1953) these bacteria characterize polluted marine areas, as does Sphaerotilus natans in polluted freshwater areas. 


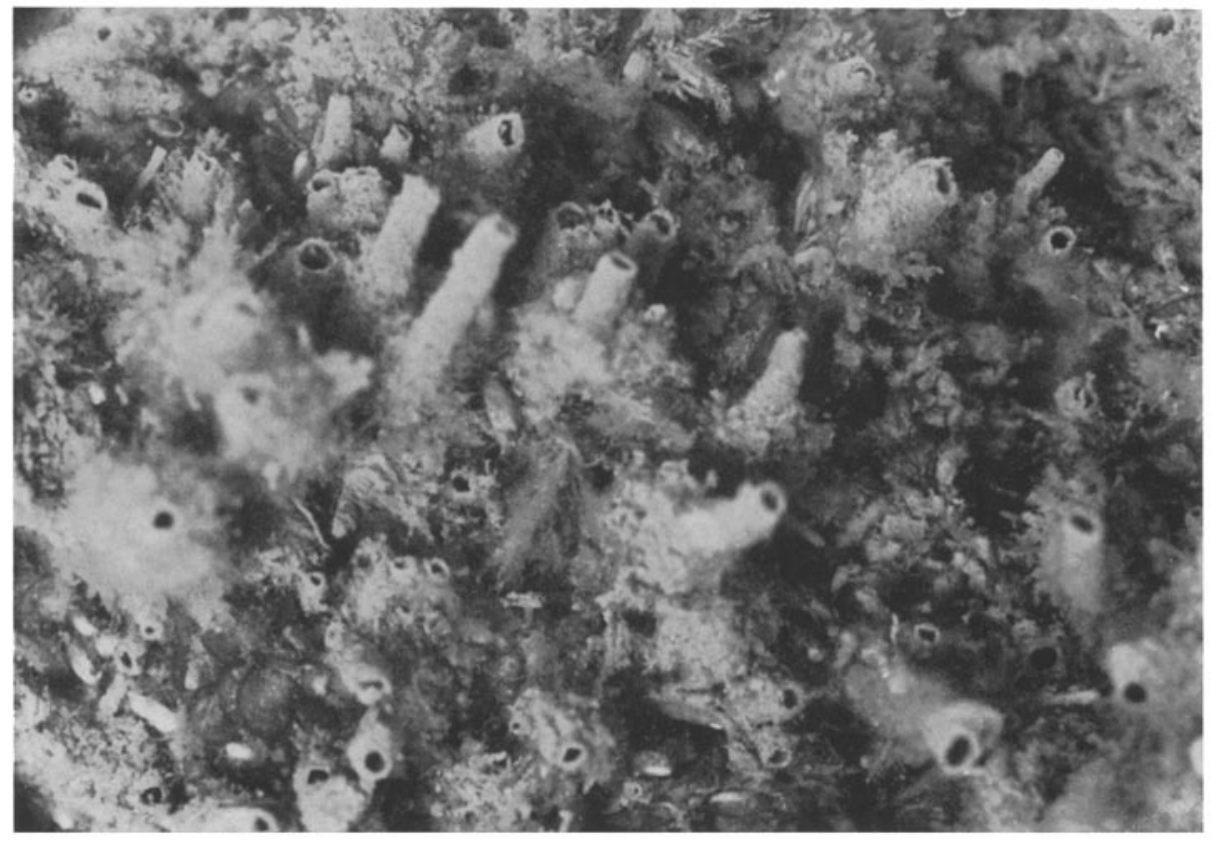

Fig. 10: "Aufwuchs" showing polychaet tubes and accumulation of mud
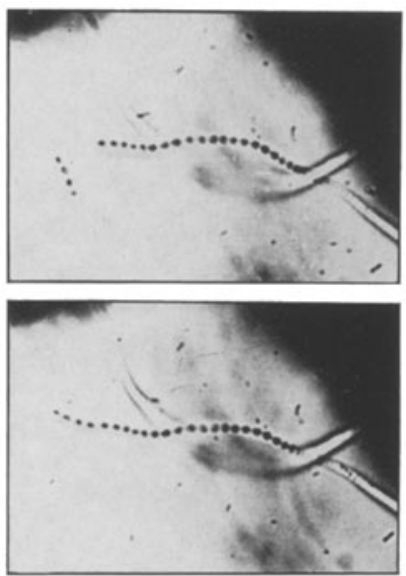

A

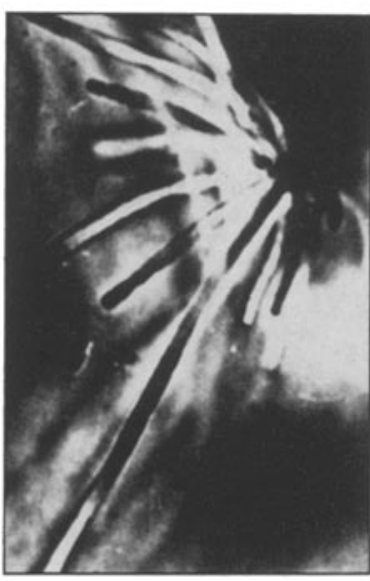

B

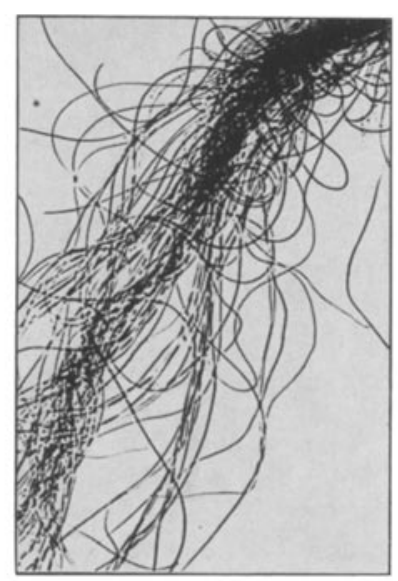

C

Fig. 11: Lencothrix mucor OERSTED. (A) Liberation of gonidia, (B) gonidial aggregation into rosettes, (C) mass development of filaments

The great numbers of bacteria, together with the large amount of organic matter, cause the strong development of different groups of invertebrates.

Microfauna: Besides a number of colorless flagellates, the ciliates are by far the most important group. Consisting of 55 species, this group exhibited the 
greatest variation among the fauna of the "Aufwuchs"--biocoenosis (Persoone 1967b). The number of microphages was always much higher than that of vegetivore, carnivore and histophagous macrophages. The list of ciliate species found in the "Aufwuchs" was quite different - also in regard to the number of individuals, their morphology and saprobic characteristics - from the one usually found in phytal or mesopsammic biotopes. According to the literature, the greater part of the species is typical for a polysaprobic and even sapropelic biotope.

$\mathrm{Me}$ i of a u n : Harpacticoid copepods were often found in very high numbers in the "Aufwuchs". The maxima calculated per $\mathrm{m}^{2}$ are 100,000 to 150,000 individuals. The dominant species was always Nitocra typica BoEck. During spring there was also a high number of Tisbe furcata (BAIRD). Harpacticoids are known as typical "Aufwuchsfresser" and "detritus feeder" (WIESER 1959, 1960).

Nematodes were exceptionally abundant. The number of worms per $\mathrm{cm}^{3} \mathrm{mud}$ were between 1,000 and 2,000, up to 7,000. Literature data show no higher numbers than 1,000. The dominant species were Monhysterids, namely Monbystera disjuncta BAstian and Monbystera parva (BASTIAN). According to the classification by Wreser (1953), these species belong to the "non-selective deposit-feeders". We have calculated that throughout the year, this group forms 80 to $100 \%$ of the nematode population.

Macrof a u a: The following macrofauna organisms were characteristic for the "Aufwuchs": the oligochaet Paranais littoralis O. F. Muller; the polychaets Polydora ciliata (Johnston), Fabricia sabella (EhrenberG), Nereis succinea Leuckart, Nereis kerguelensis Mc InTosh; the pelecypod Mytilus edulis L.; the cirripedes Balanus improvisus Darwin, Balanus crenatus Brugutere; the amphipod Corophium insidiosum CRAwFORD. Most of these species are known to thrive in polluted areas.

The number of micro-, meio- and macrofauna species was low, but the number of individuals high, as compared to normal, healthy water areas.

Using the classification proposed by SMIDT (1951), practically all organisms of the "Aufwuchs" belong to the "particle feeders"; the free living species are deposit feeders living on bacteria and detritus; the hemi-sessile and sessile species are mainly suspension feeders collecting food particles out of the free water. Thus the animals of the "Aufwuchs" make use entirely of the richness of organic matter surrounding them.

Algae are poorly developed on submerged substrates. We have found some diatoms, but no traces of any filamentous plant growth.

\section{DISCUSSION}

As an area of transition between sea and freshwater, each estuary represents an extreme habitat both for marine as well as for freshwater organisms. In order to survive and permanently establish themselves in such a biotope, organisms must be ". . . euryplastisch und sehr resistent gegen die vielfältigen Unbilden ihres rauhen Umweltklimas" (KrnNe 1964).

KüHL (1963) has summarized the physico-chemical and biological changes occuring in estuaries (Fig. 12): decrease or increase of the salinity; important increase in turbidity; decrease in number of species and individuals of typical marine and fresh- 
water plankton resulting in great quantities of dead plankton; increase of the "Aufwuchs" characterized by a small number of species, but a large number of individuals.

Thus the decrease of phyto- and zooplankton is not the only result of pollution (although it may be influenced strongly by it), since it occurs in each estuary, whether polluted or not.

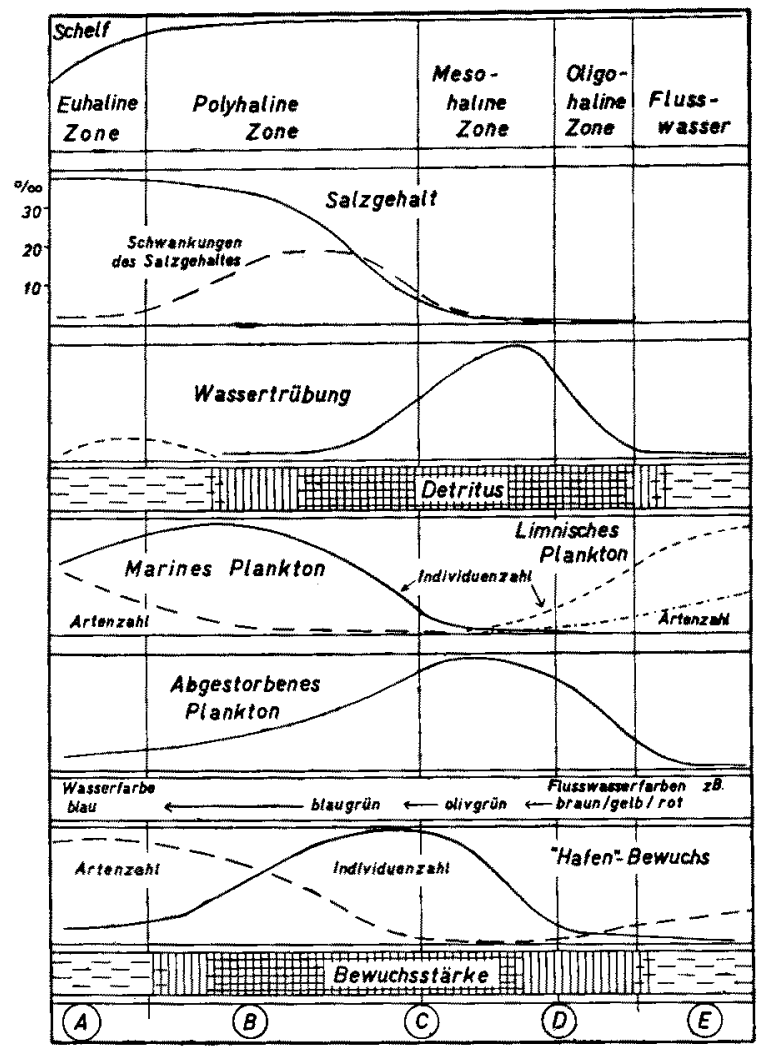

Fig. 12: Schematic illustration of physico-chemical and biological changes at different points of an estuary. (After KüHL 1963)

The strong development of some typical "Aufwuchs" species, as described by KüHL (1963), is certainly enhanced considerably in polluted areas. According to FILICE (1959), excessive growth of a few tolerant forms in the area between maximum pollution and normal water was reported from estuaries and other salt water environments.

When pollution increases beyond a critical level, even the most resistant forms cannot survive. Discharge of domestic wastes into a given body of water furnishes an additional source of food for bottom-dwelling organisms "... if the quantity of domestic waste is large, and the population of animals cannot assimilate this increase, then the number and species of animals will decrease. It is possible that the wastes 
will be in sufficient quantity to kill and exclude these animals" (REIsH 1960). CASPERs (quoted by Føyn 1965) mentions that the shallows below Hamburg, formerly maintaining a rich community of invertebrates, became completely barren due to pollution; the same seems to have happened with the benthos in the harbour of Ostend.

As we have shown, pollution in this country is not restricted to the harbour, but starts to influence more and more the nearby beaches due to tidal currents. It follows that this critical situation should be stopped as soon as possible, which in most European countries has already been done.

\section{SUMMARY}

1. Ostend, situated in the middle of the Belgian coast, is a typical seaside resort with a population of 60,000 in the winter and up to 200,000 in summer. All sewage (to the major part raw domestic sewage, to a lesser extent sewage of industrial origin) flows into its harbour, causing a daily inflow of ca. one part of sewage per 100 parts of harbour water. This heavy pollution load causes significant physico-chemical and biological consequences.

2. The number of "estuarine" bacteria has increased enormously due to the great daily input of organic matter. The number of coliform bacteria is high; it decreases towards the seaward entrance of the harbour.

3. The beach in the small vicinity of the harbour is polluted.

4. The harbour water contains low amounts of dissolved oxygen; its transparency is reduced resulting in poor or in non-existent phyto-plankton production.

5. The number of zooplankton species decreases from the outer- to the inner parts of the harbour.

6. The benthos consists of black, completely anoxic mud which strongly smells of sulfides; its content of organic matter is much higher than that of sediments in the open sea.

7. Rich development of a typical "Aufwuchs" biocoenosis which thrives on the richness in organic matter of the water.

8. Pollution of the harbour must be reduced or halted if even more serious danger are to be prevented.

A cknow ledgements: We are very indebted to Ir. van Caumenberghe and Cand.-Insp. LAMBERT who kindly procured for us useful data on the hydrography of the harbour. Sincere thanks are due to Professor Dr. J. Huble, head of the "Laboratorium voor Oecologie, Biogeografie en Algemene Biologie - Rijksuniversiteit Gent", and to Professor Dr. F. EVENs, head of the "Laboratorium voor Oecologie-Rijksuniversitair Centrum Antwerpen", for their advice and criticisms. Dr. P. DE RYCKE was very helpful in translating this paper.

\section{LITERATURE CITED}

Berger, H. \& Bringmann, G., 1953. Die Scheidensstruktur des Abwasserbakteriums Sphaerotilus natans und des Eisenbakteriums Leptothrix im elektronenmikroskopischen Bilde und ihre Bedeutung für die Systematik dieser Gattungen. Zentbl. Bakt. ParasitKde (Abt. 2) $107,318-334$. 
FrLICE, F. P., 1959. The effect of wastes on the distribution of bottom invertebrates in the San Francisco Bay estuary. Wasmann J. Biol. 17 (1), 1-17.

Føyn, E., 1965. Disposal of waste in the marine environment and the pollution of the sea. Oceanogr. mar. Biol. A. Rev. 3, 95-114.

Gunkel, W., 1963. Daten zur Bakterienverteilung in der Nordsee. Veröff. Inst. Meeresforsch. Bremerh. (Sonderbd) 1, 80-90.

- 1964. Einwirkungen des kalten Winters 1962/63 auf die Bakterienpopulationen vor Helgoland. Helgoländer wiss. Meeresunters. 10, 246-256.

Harold, R. \& Stanier, R. Y., 1955. The genera Leucotbrix and Thiothrix. Bact. Rev. 2, 49-58.

Harvey, H. W., 1955. The chemistry and fertility of seawaters. University Press, Cambridge, $224 \mathrm{pp}$.

Hata, Y., Kadota, H., Miyoshi, H. \& Kimata, M., 1965. Microbial production of sulfides in polluted coastal and estuarine regions. In: Advances in water pollution research. Proceedings of the 2nd International Conference held in Tokyo, August 1964. Vol. 3. Ed. by E. A. Pearson. Pergamon press. Oxford, 287-298.

KrnNe, O., 1964. Physiologische und ökologische Aspekte des Lebens in Ästuarien. Helgoländer wiss. Meeresunters. 11, 131-156.

Koske, P. H., Krumm, H., Rheinhermer, G. \& Szekielda, K. H., 1966. Untersuchungen über die Einwirkung der Tide auf Salzgehalt, Schwebstoffgehalt, Sedimentation und Bakteriengehalt in der Unterelbe. Kieler Meeresforsch. 22, 47-63.

Kruma, H. \& Rhernhermer, G., 1966. Untersuchungen zur Hydrographie, Schwebstoffzusammensetzung und Bakteriologie des Nord-Ostsee-Kanals. Kieler Meeresforsch. 22, 121-127.

KüHL, H., 1963. Schiff bewuchs und Hafenbewuchs. Scbiff Hafen 15, 1-4.

Lafontaine, A., Maeyer-Cleempoel, S. de \& Bouquiaux, J., 1956, Recherches sur les entérobactériacées des eaux de mer du littoral belge. Archs belg. Med. soc. 14, 53-66.

Lefevere, S., Leloup, E. \& Meel, L. van, 1956. Observations biologiques dans le port d'Ostende. Mém. Inst. r. Sci. nat. Belg. 133, 1-157.

MeEL, L. van, 1957. Le milieu marin au bateau-phare ‘West-Hinder`. Période 1951-1955. Bull. Inst. r. Sci. nat. Belg. 33 (4), 1-36.

- 1964. Etudes hydrobiologiques sur les eaux saumâtres de Belgique. VII. Le microplancton des eaux du port d'Ostende. Bull. Inst. r. Sci. nat. Belg. 40 (4), 1-17.

Leloup, E., Meel, L. van, Polk, P., HalewyCK, R. \& Gryson, A., 1960-63. Recherches sur l'ostréiculture dans le Bassin de Chasse d'Ostende en 1960, 1962, 1963. Ministère de l'Agriculture (Bruxelles), 89, 58, 48 pp.

- \& Polk, P., 1966. Observations sur la salissure dans le port d'Ostende. Bull. Inst. $\gamma$. Sci. nat. Belg. 42 (23), 1-14.

PAoletr, A., 1964. Microörganismes pathogènes dans le milieu marin. In: Pollutions marines par les microörganismes et les produits petroliers. Symposium de Monaco, Avril 1964. Ed. par la Commission Internationale pour l'Exploration Scientifique de la Mer Méditerranée, Monaco. Secrétariat Général de la Commission, Paris, 133-184.

PAUW, N. DE, 1966. Oecologische studie van het plankton in de haven van Oostende gedurende 1965. Licentiaatsverhandeling, Rijksuniversiteit Gent (unpubl.).

Persoone, G., 1965. The importance of fouling in the harbour of Ostende in 1964. Helgoländer wiss. Meeresunters. 12, 444-448.

- 1966. Contributions à l'étude des bactéries marines du littoral belge. III. Milieux de culture et ensemencements. Bull. Inst. r. Sci. nat. Belg. 42 (6), 1-14.

- 1967a. Oecologische studic van de aangroei op ondergedompelde substraten in de haven van Oostende. Doctoraatsthesis (unpubl.).

- 1967b. Ecologie des protozoaires dans les salissures de substrats immergés dans un port de mer. Protistologica (in press).

Raymont, J. E. G., 1963. Plankton and productivity in the oceans. Pergamon Press, London, $660 \mathrm{pp}$.

REISH, D. J., 1960. The use of marine invertebrates as indicators of water quality. In: Proceedings of the 1 st International Conference on waste disposal in the marine environment, Berkeley, Calif., 1959. Ed. by E. A. Pearson. Pergamon Press, Oxford, 92-103. 
Rhennhermer, G., 1966. Einige Beobachtungen über den Einfluß von Ostseewasser auf limnische Bakterienpopulationen. Veröff. Inst. Meeresforsch. Bremerh. (Sonderbd) 2, 237-244.

Scrulz, B., 1925. Aerologische und hydrographische Beobachtungen der deutschen MarineStationen während der Kriegszeit 1914-1918. II. Hydrographische Untersuchungen. B. Beiträge zur Kenntnis der Gezeiten an der flandrischen Küste und auf der unteren Schelde. Aus Arch. dt. Seew. 43, 1-63.

Sreburth, J. MC. N., 1965. Role of algae in controlling bacterial populations in estuarine waters In: Pollutions marines par les microörganismes et les produits petroliers. Symposium de Monaco, Avril 1964. Ed. par la Commission Internationale pour l'Exploration Scientifique de la Mer Méditerranée, Monaco. Secrétariat Général de la Commission, Paris, 217234.

SмIDT, E. L. B., 1951. Animal production in the Danish Waddensea. Meddr Komm. Danm. Fisk.-og. Havunders. 11, 1-151.

WIESER, W., 1953. Die Beziehung zwischen Mundhöhlengestalt, Ernährungsweise und Vorkommen bei freilebenden marinen Nematoden. Eine ökologisch-morphologische Studie. Ark. Zool. 4 (26), 439-484.

- 1959. Zur Okologie der Fauna mariner Algen mit besonderer Berücksichtigung des Mittelmeeres. Int. Revue ges. Hydrobiol. 44, 137-180.

- 1960. Benthic studies in Buzzards Bay. II. The meiofauna. Limnol. Oceanogr. 5, 121-137.

ZoBell, C. E., 1957. Marine bacteria. Mem. geol. Soc. Am. 67 (1), 1035-1040.

- \& Feltham, C. B., 1942. The bacterial flora of a marine mud flat as an ecological factor. Ecology 23, 69-78.

\section{Discussion following the paper by Persoone \& DE PAUW}

GuNKel: Liegen Untersuchungen darüber vor, in welchem Maße ein Austausch $z$ wischen Hafenwasser und Wasser der freien See stattfindet? Inwieweit werden Abwässer aus dem Hafen heraus entfernt?

Persoone: We have found no data on the time needed for the renewal of the whole water volume of the harbour of Ostend.

CARRUTHERs: I would very much like to have heard more about the impact of this highly polluted harbour on the waters of the North Sea because the currents along your coast have been better observed than have the currents anywhere else in the North Sea. I refer to the extremely practical drifting-raft work of B. Schulz (1916).

Persoone: Unfortunately we have not been able yet to study this very important aspect in more detail.

Postma: Anaerobic conditions also occur in harbours without important pollution. In these cases oxygen deficiency is due to accumulation of organic detritus entering the harbour from the adjacent part of the open sea. My question is whether the speaker can indicate how much of the organic matter, accumulated in the harbour of Ostend, comes from sewage and how much from the North Sea.

Persoone: According to the work by Lefevere, Leloup \& van Meel (1956), the sediments in the outer- and inner-harbour originate for the greater part from the canals Ostend-Bruges and Noord-Eede, both of which are very polluted as we have shown. 